\title{
Lentiform Fork Sign: Neuroradiologic Features and Differential Diagnosis
}

\section{Lentiform Fork Belirtisi: Nöroradyolojik Özellikleri ve Ayırıcı Tanısı}

\author{
(1) Fettah Eren ${ }^{1}$, (1) Ahmet Hakan Ekmekçi² (1) Şerefnur Öztürk²
}

'University of Health Sciences, Konya Training and Research Hospital, Clinic of Neurology, Konya, Turkey ${ }^{2}$ Selcuk University Faculty of Medicine, Department of Neurology, Konya, Turkey

Keywords: Lentiform nucleus, fork sign, neuroradiology

Anahtar Kelimeler: Lentiform nükleus, fork belirtisi, nöroradyoloji

\section{Dear Editor,}

A 56-year-old female was admitted with dizziness and not recognizing surrounding people for 10 days. Total blood count, biochemical, hormonal and metabolic tests performed 10 days previously were normal. After the initiation of her symptoms, piracetam $1800 \mathrm{mg} / \mathrm{d}$ and betahistine $48 \mathrm{mg} / \mathrm{d}$ were started. The patient was admitted to our clinic because her symptoms did not improve. She had no history of chronic disease and was taking no medication. She was stuporous and her cooperation was limited. Her muscle strength was $4 / 5$ in the 4 extremities and deep tendon reflexes were hypoactive. In addition, she had generalized rigidity. The laboratory tests were as follows: white blood cell: 11 (normal:
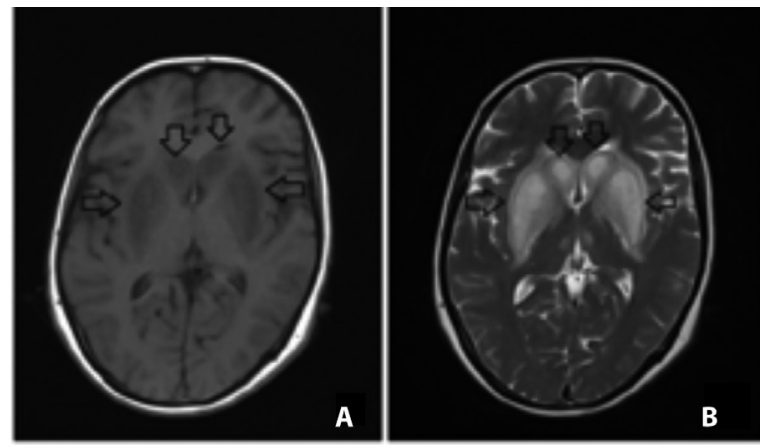

3.5-10.5) K/uL, hemoglobin: 11.1 (normal: 13.5-17.5) g/dL, thrombocyte: 212 (normal: 150-450) K/uL, B12: 444 (normal: 211-911) $\mathrm{pg} / \mathrm{mL}$, and folic acid: $8.62(9-24) \mathrm{ng} / \mathrm{mL}$. Fasting blood glucose, liver and kidney function tests, lipid profile, creatinine phosphokinase, electrolytes, blood gas test and thyroidstimulating hormone were normal in routine biochemical tests. No local or systemic diseases were detected. She had no medical history or laboratory findings suggestive of intoxication.

Magnetic resonance imaging showed bilateral symmetric hyperintense lesions in the nucleus caudatus, globus pallidus, and putamen at the level of basal ganglia in T2 and fluidattenuated inversion recovery-weighted images. There was no

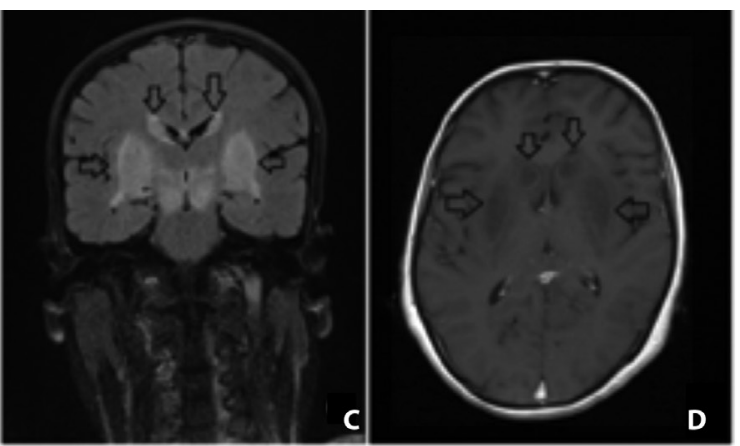

Figure 1. Magnetic resonance imaging; A) T1 axial, B) T2 axial, C) FLAIR coronal, D) T1 contrast axial: Lesions in the bilateral basal ganglia are symmetric and hyperintense in T2 and FLAIR-weighted imaging and hypointense in T1-weighted imaging, and there is no pathologic contrast enhancement.

Address for Correspondence/Yazışma Adresi: Fettah Eren MD, University of Health Sciences, Konya Training and Research Hospital, Clinic of Neurology, Konya, Turkey

Phone: +903322244007 E-mail: dreren42@hotmail.com ORCID ID: orcid.org/0000-0001-6834-0827 Received/Geliş Tarihi: 22.12.2017 Accepted/Kabul Tarihi: 25.01 .2018 Presented in: The case was presented as printed poster at the $51^{\text {st }}$ National Congress of Neurology in Antalya at November 2015. 

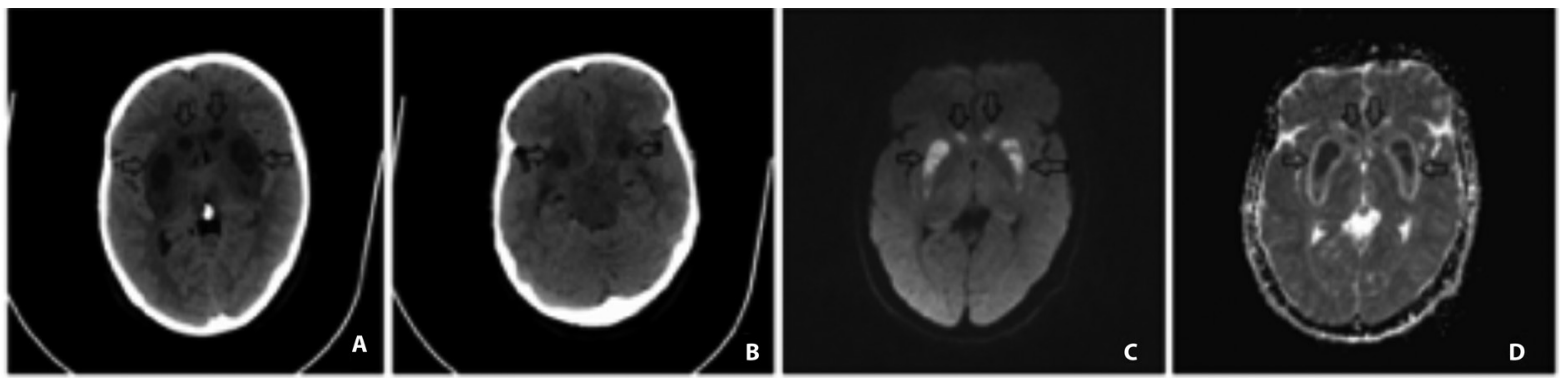

Figure 2. A, B) Cerebral tomography. C) Diffusion-weighted imaging. D) ADC-weighted imaging: Bilateral basal ganglia involvement and diffusion restriction

contrast enhancement in the lesions (Figure 1). The lesions were hypodense in cerebral tomography, hyperintense in diffusionweighted imaging, and hypointense in ADC-weighted imaging (Figure 2). The lesions were considered as idiopathic "lentiform fork sign". Valproic acid was initiated with a dose of $1000 \mathrm{mg} / \mathrm{d}$ for the myoclonic seizures, which occurred at the follow-up. At the 3-month follow-up, her motions had slowed down and she could continue her daily life, partially dependent.

"Lentiform fork sign", which is a radiologic definition, describes bilateral basal ganglia lesions $(1,2)$. Metabolic acidosis is the condition that should examined as a priority $(1,3)$. Hypoglycemia, hyperglycemia, vascular conditions, hypoxic and uremic encephalopathies and intoxications can cause these lesions (4). Vasogenic edema is supposed to be involved in the etiopathogenesis. Irreversible cystic degeneration may occur due to edema (5). Patients without metabolic acidosis presenting with "lentiform fork sign", as in our patient, is rarely reported. It should be kept in mind as a rare neuroradiologic condition.

\section{Ethics}

Informed Consent: Informed consent was obtained from a member of the patient's family.

Peer-review: Internally peer-reviewed.

Authorship Contributions

Surgical and Medical Practices: F.E., A.H.E., Ş.Ö., Concept:
F.E., A.H.E., Ş.Ö., Design: F.E., A.H.E., Ş.Ö., Data Collection or Processing: F.E., A.H.E., Ş.Ö., Analysis or Interpretation: F.E., A.H.E., Ş.Ö., Literature Search: F.E., A.H.E., Ş.Ö., Writing: F.E., A.H.E., Ş.Ö.

Conflict of Interest: No conflict of interest was declared by the authors.

Financial Disclosure: The authors declared that this study received no financial support.

\section{References}

1. Kumar G, Goyal MK. Lentiform fork sign: a unique MRI picture. Is metabolic acidosis responsible? Clin Neurol Neurosurg 2010;112:805-812.

2. Yoon $\mathrm{CH}$, Seok JI, Lee DK, An GS. Bilateral basal ganglia and unilateral cortical involvement in a diabetic uremic patient. Clin Neurol Neurosurg 2009;111:477-479.

3. da Rocha AJ, Maia AC Jr, da Silva CJ, Sachetti SB. Lentiform fork sign in a child with dialysis disequilibrium syndrome: a transient MRI pattern, which emphasizes neurologic consequence of metabolic acidosis. Clin Neurol Neurosurg 2013;115:790-792.

4. Beltz EE, Mullins ME. Radiological reasoning: hyperintensity of the basal ganglia and cortex on FLAIR and diffusion-weighted imaging. Am J Roentgenol 2010;195(Suppl 3):1-8.

5. Hovda KE, Hunderi OH, Rudberg N, Froyshov S, Jacobsen D. Anion and osmolal gaps in the diagnosis of methanol poisoning: clinical study in 28 patients. Intensive Care Med 2004;30:1842-1846. 